\title{
Animal Protection Law in Australia: Bound by History
}

Steven White

Abstract This chapter examines changing attitudes to the treatment of animals in $19^{\text {th }}$ century Britain, tracing the effects of change through to the first British animal protection legislation in 1822, and beyond to the law of the Australian colonies. By the early part of the twentieth century a number of key facets of animal protection regulation were established: the adoption of the generic 'no unnecessary suffering' standard in assessing the extent of cruelty to animals allowed; the use of exemptions from the generic prohibition against cruelty; the imposition of duties to provide for the needs of an animal; and the establishment of one of the key institutional actors in the animal protection field, the RSPCA. As well, the Australian colonies faithfully reproduced an understanding of domesticated animals as personal property. Analysis of the development of animal protection law in Queensland provides a "representative sample" of the adoption of animal protection law in the States and Territories more broadly. In Queensland, as in other similar jurisdictions, the question remains whether the present day animal protection regulatory framework amounts, in essence, to a $19^{\text {th }}$ century answer to $21^{\text {st }}$ century concerns.

\section{Introduction}

This chapter examines the evolution of animal protection law in Australia. The United Kingdom (UK) antecedents of Australian animal protection regulation will be explored first, followed by a description of the way in which regulation unfolded across newly colonised Australia. Drawing on the established literature addressing the history of UK legislative developments, this chapter summarises the historical context from which contemporary Australian regulation of animal protection emerged. An understanding of the historical foundations of the prevailing regulatory regime is important for at least two key reasons. First, the broad model of

\footnotetext{
S. White

Griffith University

Brisbane, Australia

email: steven.white@griffith.edu.au
} 
regulation established by around the end of the $19^{\text {th }}$ century in Australia is one which has persisted to the present day - a prohibition against cruelty under threat of state sanction and an exemption from prosecution for a range of practices concerning animals which might otherwise be legally cruel. Second, the emergence of animal protection law in the $19^{\text {th }}$ century was driven by changing attitudes to the significance of animal suffering. During the nineteenth century animals were increasingly recognised as sentient creatures capable of experiencing pain and suffering and therefore deserving of humane protection. The legal application of an ethic of humaneness in the protection of animals has proven to be durable, continuing to inform contemporary regulation.

Section 2 of this chapter provides a brief account of the attitudinal changes towards animals occurring in the $18^{\text {th }}$ and $19^{\text {th }}$ centuries in the UK. These changes preceded the passage of the first Act in the UK proscribing cruelty to animals, legislation later replicated in the Australian colonies. Radford (2001, p 3) points out that '[c]ruelty to animals pervaded eighteenth-century England; the majority of the population simply disregarded their suffering, but a significant proportion positively revelled in it' However, it was also during the latter part of the $18^{\text {th }}$ century that public consciousness of animal cruelty increased, stimulated by the public nature of cruelty in an increasingly urbanised landscape and by social reform movements occurring across a number of policy fronts, domestically and abroad.

Section 3 summarises the key early legislative developments in the UK. Proposed animal protection legislation was presented to the UK Parliament as early as 1800, but it was not until 1822 that the first bill was passed. The passage of this legislation was quickly followed by the establishment of a key and enduring animal welfare institution, the Royal Society for the Prevention of Cruelty to Animals (RSPCA), tasked with an educative and enforcement role. The RSPCA was founded by committed individuals active across a range of humanist projects, including the abolition of slavery, improved working conditions for factory workers and the protection of children. It was created at a time when private individuals enforced much criminal law. The role of inspectors of the RSPCA in enforcing the legislation was, from the outset, akin to that of a private police force. This remains the case 
today, despite the State assuming the near-exclusive responsibility for the enforcement of criminal law.

Section 4 charts the importation of animal protection law into Australia. After an initial and unapologetic “copying” of UK legislation, adapted for domestic purposes, a distinctively Australian approach subsequently emerged. This approach was reflected, for example, in the inclusion of animal welfare protections in police legislation rather than in stand-alone anti-cruelty statutes. After federation, the animal protection project was largely undertaken in an uncoordinated way by the States (and later Territories), with a putative lack of constitutional power sidelining the Commonwealth. Much later - under the pressure of international scrutiny - a more coordinated approach to regulation developed with the introduction of codes of practice for the welfare of farm animals. From the introduction of the first code, in 1980, the Commonwealth assumed an increasingly significant role in leading policy reform and seeking the implementation of an agenda of national consistency in animal protection regulation. More recently, the Commonwealth has abandoned the field of domestic animal welfare policy, drawing into doubt the viability of the consistency project. Significantly, along with the adoption of UK-inspired animal protection legislation, the Australian colonies embedded an underlying legal categorisation of domesticated animals as personal property.

Section 5 concludes this chapter by narrowing the focus to a particular Australian jurisdiction. A brief overview of the development of animal protection in Queensland provides a "representative sample" of the adoption of animal protection law in the States and Territories. Such a focus is illustrative at a broad level of regulatory structure, while at the same time acknowledging that the history of other jurisdictions will be marked by their own particular idiosyncrasies.

\section{The Emergence of an Animal Protection Sensibility in the United Kingdom}


In one sense, the story of the emergence of animal protection law in $19^{\text {th }}$ century

England ${ }^{1}$ is the story of industrialisation, urbanisation and the growth of a civicminded, metropolitan middle class. ${ }^{2}$ As Armstrong and Botzler (2008, pp 4-5) put it:

[i]n England, the growth of towns and the emergence of an industrial order in which animals became increasingly marginal to production were significant factors in the development of concern for animals’ rights. The reformist ideas were expressed by either well-to-do townspeople or by educated country clergy. The professional middle classes were unsympathetic to the warlike traditions of the aristocracy, which had valued hunting because it simulated warfare, and cock-fighting and bear-baiting because they represented private combat. $^{3}$

As some animals, especially horses, were becoming increasingly marginalised 'workers' in the face of expanding industrial production, other animals were assuming an increasingly significant role in the households of some families (Armstrong and Botzler, 2008, p 4):

pet keeping had been fashionable among the well-to-do as well as among religious orders in the Middle Ages, but it was in the sixteenth and seventeenth centuries that pets seem to have established themselves as a normal feature of the middle-class household . . . Gradually, the idea that tamed animals were property was developed. Pets were distinguished by being allowed into the house and by going to church with their human companions, by being given individual personal names, and by never being eaten. The spread of pet-keeping created the psychological foundation for the view that some animals were entitled to moral consideration.

Hilda Kean (1998, p 28) argues that the increased visibility of animals in an urban setting was particularly important in shifting sentiment about the treatment of animals:

\footnotetext{
${ }^{1}$ While this chapter focusses on the emergence of animal protection law in the UK, as the coloniser of Australia, similar developments were occurring in the newly independent United States (Favre and Tsang, 1993).

2 Turner (1980, p 25) suggests that 'urbanisation and industrialisation in some way helped to generate the new concern for beasts. But this is merely an observation, not an explanation'.

${ }^{3}$ Ryder (2000, p 147) acknowledges the significance of urbanisation but also stresses that this should not be accepted in an unqualified way. He points out that 'some of the worst cruelties towards nonhumans in Victorian Britain were inflicted by urban dwellers in the pursuit of objects that were neither agricultural nor sporting: vivisection, the fashion industry and the daily abuse of horses are three major examples. Furthermore, although the animal protection movement in America was largely an urban phenomenon, in Britain this was not so true; many of the movement's leaders, for instance, were country clergymen or landowners (admittedly often with business in London) . . . indeed the industrial middle class played little part in the British animal welfare crusade'.
} 
Clearly what animals you saw depended on where you lived. In the country there were, of course, animals on farms, birds and wild animals in the fields and domestic pets in the home. However by the start of the nineteenth century Britain was already an urban country. The cities would be the places where animals were increasingly seen and where their treatment would be most hotly debated.

London was a focal point for the use of and trade in animals, with a large live market for farm animals on the outskirts of the city, numerous touring animal menageries, permanent exhibitions of animals, animals used in public 'entertainment' such as bullbaiting and animals used for transportation of people and goods (Kean, 1998). ${ }^{4}$ Changing sentiment towards animals could not be explained by simplistic notions of a loss of connection with the countryside, or by the idea that 'urban isolation from animal farming had nourished emotional attitudes which were hard to reconcile with the exploitation of animals by which most people lived’ (Kean, 1998). An analysis which values animals in the countryside as 'real' animals and those in the towns as sentimental echoes of a lost way of life (Kean, 1998, p 30):

fails to recognize the abundance of animals living in cities in the early nineteenth century and their economic, as well as cultural, importance for the inhabitants. It also fails to acknowledge the importance of the role of sight in developing the relationship between seeing ill-treatment and creating change. The 'farm' animals that lived and worked in London would also be the first type of animals to benefit from legislation. ${ }^{5}$

Kean (1998, p 24) acknowledges that those 'supporting humane treatment for animals adhered to no one political or ideological set of beliefs'. Increasingly, though, 'the way in which people treated animals became a distinguishing feature of being humane and of membership of a new middle class and respectable working class’ (Kean, 1998, p 24). Debates on animal protection occurring in Parliament at the turn of the nineteenth century were not 'simply about the development of changing attitudes

\footnotetext{
${ }^{4}$ Bull-baiting 'involved tying a bull to a stake and setting one or more dogs upon it, the object being for the dogs to get hold of, and hang on to, the bull's nose' (Radford, 2001, p 18). Bull-baiting and bearbaiting date back to the Middle Ages. The former arose as practise of butchering. In the medieval period 'baiting bulls with dogs was believed to improve the quality of the meat, and for this reason most medieval towns enforced by-laws stipulating that bulls should be baited before slaughter' (Griffin, 2005, p 42). These regulations had fallen into disuse by the eighteenth century, but the practise remained as a form of entertainment. Bear-baiting had always been an entertainment, 'patronised by royalty, nobility, and civic elites' (Griffin, 2005, p 42).

${ }^{5}$ Siobhan O'Sullivan (2011) has utilised a 'visibility' argument to underpin a political science analysis of prevailing regulation of animal protection.
} 
towards animals'. Such debates partly reflected significant challenges to the status quo represented by more sympathetic religious responses to the plight of animals, the emergence of a rights discourse for the disenfranchised following the French Revolution and the publication of Thomas Paine's Rights of Man and, significantly, the work of utilitarian Jeremy Bentham. ${ }^{6}$ The ideas expressed at this time contributed to a climate in which the concept of animal protection could be taken seriously. Although Paine did not address the plight of animals, 'the call for society to recognize that all human beings had the same moral and civil rights, on the basis of the nature of each person and regardless of their social status, caused at least some to consider applying a similar principle to other species’ (Radford, 2001, p 24). Radford acknowledges that arguments for the extension of rights to animals were not 'common or widely accepted' in $18^{\text {th }}$ century Britain, 'but there are examples from this period of the language of rights being applied to animals'.

Concerns about the treatment of animals were part of a wider movement for humanitarian reform, with a focus on the pain caused by cruel practices. Through the $18^{\text {th }}$ century a range of activities were targets of reform, including 'blood sports, public executions, treatment of the insane, punishment by flogging in the armed services, corporal punishment of children, and sport that caused serious injury' (Munro, 2001, p 11). Animal protection took its place as part of a 'general movement which gathered pace during the nineteenth century, often promoted by the same people, which was concerned to improve conditions across a range of areas’ (Radford, 2001, p 48). Child protection and animal protection campaigns emerged at around the same time, with humanist activists also agitating for improved employment conditions, prisons and treatment of the poor. A notable feature of reform in these

\footnotetext{
${ }^{6}$ For more detailed accounts of the significance of each of these developments see Radford (2001). Radford (2001, p 59) concludes that the 'impetus for the introduction of animal protection legislation during the first part of the nineteenth century was founded on much more than mere sentimentality. Greater understanding of animal physiology, a reassessment of man's place in the world, the development of a secular morality, the increasing influence of middle-class values, concern for social discipline and stability, a political and legislative system which was responsive, the individual campaigners to carry the cause forward, and the endorsement of the higher ranks of society were all factors in legislative protection becoming a reality. It represented a confrontation between the old, preindustrial, paternal, rural community, dominated by local customs, identity and administration, and the new, urbanized society governed from London'. See also Ryder (2000) who cites a range of prominent artistic, philosophical, and cultural figures in eighteenth century Britain extolling the need for better treatment of animals (such as Samuel Johnson, Percy Shelley, Jeremy Bentham, William Blake and Robert Burns).
} 
disparate areas was the similarity of the legislation which emerged addressing these societal problems. For example, legislation addressing the mistreatment of children was labelled as "prevention of cruelty to children”, and made it an offence 'wilfully to ill-treat, neglect, abandon, or expose a child in any manner likely to cause it suffering or injury to health' (Radford, 2001, p 50). As will be shown in Section 3, animal protection legislation passed earlier in the $19^{\text {th }}$ century employed strikingly similar language.

The motivations of those seeking legal change in support of animal protection were diverse and, as Jamieson (1991a, p 21) suggests, 'dissecting the motives of the early nineteenth century protagonists and antagonists of animal protection legislation ... violates both the integrity and the confusion of their ideals'. However, there seems little doubt that change in the understanding of the moral significance of animals, and of their vulnerability to pain, was important. This new sensibility went beyond a concern to protect property or to control the behaviour of the masses (Kean, 1998, p 31):

The rise of organized political discussion and then of societies to protect animals became a distinctive part of the creation of new political and moral sensibilities. Changes in the law were invoked not just to defend property nor to regulate the behaviour of the rabble and seditious agitators; they also had the effect of giving protection to those unable to speak for themselves. The role of advocate and protector was being established to invoke the cause of those literally without human speech, dumb animals.

With shifts in popular attitudes to the plight of some animals, fuelled by increasing urbanisation and an increasingly pluralistic and vibrant intellectual debate, the possibility of political change was fostered, reflected in attempts to legislate for animal protection beginning in 1800 .

\section{Early Animal Protection Legislation in the United Kingdom}

Early attempts at legislative reform of animal protection in the UK targeted the prohibition of bull-baiting, once widely considered a respectable past-time, but by 1800 a popular recreational activity for lower class Britons (Kean, 1998). Bills introduced in the House of Commons in 1800 and 1802 respectively were partly 
motivated by concerns about cruelty to the animals involved, but even more by concerns about the undesirable public order consequences of bull-baiting, including drinking, gambling and interference with work. Both Bills were voted down. A key opposition argument was that the Bills reflected a censorious approach to working class past-times; they betrayed a 'double standard' where bull-baiting would be prohibited, but other recreational activities such as fishing, hunting and shooting, and horse racing would continue.

The next reform effort occurred in 1809, when Thomas Erskine introduced a Bill into the House of Lords prohibiting malicious and wanton cruelty to animals. As Radford points out, this Bill differed from the bull-baiting Bills in a number of important respects. First, it was not confined to one class of animal or activity, but extended to any circumstance involving cruelty to horses, donkeys, oxen, sheep and pigs (although it was subsequently amended to be confined to 'beasts of burden'). In this respect, the Bill clearly anticipates contemporary regulation. Second, the controversial matter of defining ‘cruelty’ was avoided, with the Parliament leaving it to the courts to judge whether or not an act or omission would constitute cruelty. Third, the justifications put forward for the Bill shifted sharply towards a focus on the protection of animals, even if concern about public order remained relevant. Erskine emphasised the daily cruelty meted out to animals, recognised the shared sentiency of humans and animals and acknowledged the direct moral duty of protection owed by humans to animals. Fourth, Erskine argued that mere education is not enough; State intervention was required to establish and promote the obligations owed by humans to animals. Again, this sensibility underpins contemporary regulation, and is consistent with Ryder's argument that 'by the end of the eighteenth century in England the basic principles of the modern animal protection position were established. These are that nonhumans, like humans, can suffer pain, and that pain entitles them to legal as well as moral rights’ (Ryder, 2000, p 72).

Although Erskine's Bill passed the House of Lords, it was comfortably defeated in the House of Commons. One of the arguments made against the Bill - in a context where 'most prosecutions were brought by private individuals rather than the State' - was that the generality of the legislation meant it would be manipulated by fanatics and by over-zealous enforcers seeking to impose their sensibilities on members of the 
working class (Radford, 2001, p 37). The lack of definitional clarity would also mean that the legislation would be applied in an inconsistent way by different judges. In part, these represent a concern not to "open the floodgates" in an entirely new area of legal liability, and to avoid the injustice that may go along with an inconsistent application of the law. The leading opponent of the legislation, William Windham MP, argued that the proper treatment of animals was a matter of 'manners and morals', and not the province of Parliament. The attempt to legislate for animal protection 'raised the fundamental question of whether it was either legitimate or desirable for the State to define and impose common standards of public morality' (Radford, 2001, p 54). This concern resonated with debates across a range of areas, in which the sanctity of the classic liberal private-public divide was asserted.

Windham also repeated his earlier criticism of the bull-baiting Bills - by not specifically including field sports such as hunting and shooting as cruel, legislators would be imposing a double standard on the working class (Radford, 2001). Erskine tried again to pass a similar Bill a year later, but in the face of even stronger opposition withdrew the proposed legislation.

Richard Martin, MP for Galway, introduced a new Bill into the House of Commons in 1820 prohibiting ill-treatment against horses and other animals by third parties. The Bill passed the Commons, but not the House of Lords. Martin persisted, and two years later, even in the face of opposition by the Attorney-General, succeeded in shepherding through the first animal protection statute in the UK (Radford, 2001). Martin's Act ${ }^{7}$ received the Royal Assent on 21 June 1822. The Act made it 'an offence for any person or persons wantonly and cruelly to beat, abuse, ill-treat any horse, mare, gelding, mule, ox, cow, heifer, steer, sheep or other cattle'. ${ }^{8}$ Prosecutions could be initiated on complaint to a Magistrate, with fines of up to five

\footnotetext{
${ }^{7}$ An Act to prevent the cruel and improper Treatment of Cattle 3 Geo IV, c 71.

${ }^{8}$ Although often-cited as the first animal protection statute, Radford (2001, p 39) notes 'an Irish law of 1635 which prohibited the pulling of wool off sheep and the attaching of ploughs to horses' tails which was enacted at least in part because of the cruelty caused by these practices'. He also points to legislation passed in Massachusetts Bay Colony in 1641 which provided that 'No man shall exercise any Tirrany or Crueltie towards any bruite Creature which are usuallie kept for man's use. Anti-cruelty legislation was also passed in Maine the year before Martin’s Act was passed'. Tim Bonyhady (2000, pp 49-50) suggests that a restriction imposed on the taking of birds on Norfolk Island in 1790 by commandant Robert Ross was 'not just concerned to ensure a continued supply of food ... Nor was he just mimicking existing metropolitan or colonial practice. His laws included what was probably the world's first prohibition of cruelty to animals'.
} 
pounds applying to offenders. The Act also contained a provision allowing a fine to be imposed on those bringing vexatious or frivolous claims.

Emboldened by his 1822 success, Martin introduced a range of further Bills over the next four years seeking to extend the scope of protection provided by the initial statute (including extending protection to other animals such as cats, dogs and monkeys). None of these further Bills succeeded. However, Martin also contributed to another major development in animal protection regulation - he was one of the founders of the Society for the Prevention of Cruelty to Animals (SCPA). Although Martin was an assiduous enforcer of the legislation, at a time when private individuals rather than the State largely initiated prosecutions, 'an individual, working alone, could only achieve so much; for greater effectiveness, a formal organization charged with protecting animals was required' (Radford, 2001, p 40). The SPCA was founded in 1824 in a London coffee shop at a meeting comprising Parliamentarians (including Martin and Wilbur Wilberforce), clergy, and newspaper editors and correspondents. From the outset the SPCA resolved to improve the treatment of animals through education and enforcement. An inspector was appointed, and 149 prosecutions were successfully run in the first year of operations. As Harrison (1973, p 793) notes:

The R.S.P.C.A. is particularly interesting among nineteenth century pressure-groups because it did not rely solely on the police to enforce the law. In its protection of animals, [a] major achievement was to create agencies which specialized in enforcing the law - a sort of private police force with a strictly limited area of concern.

After running into serious financial difficulties through the 1820 s the society came close to being dissolved, before recovering and prospering over the next decade. In 1837 'Royal patronage followed' and 'Queen Victoria gave permission to add the royal R in 1840' (RSPCA UK, n.d.). Two aspects of the creation of the RSPCA UK stand out in the context of present day regulation of animal protection. The first is that the organisation assumed the role of prosecution in an age where the State was not the primary enforcer of penal legislation. ${ }^{9}$ Although that age has passed, the

\footnotetext{
${ }^{9}$ Ritvo (1987, p 145) suggests that '[b]y maintaining what amounted to a private police force, the society defined itself as a quasi-governmental institution and its mission as the surveillance and control of the dangerous perpetrators of cruelty to animals. This whole-hearted endorsement of interventionist
} 
RSPCA - a non-government, charitable body - continues to be a key prosecution agency, including in various States and Territories in Australia. Second, the main regulatory tools adopted by the RSPCA in the early $19^{\text {th }}$ century have remained largely unchanged. Officers of the RSPCA in most Australian jurisdictions have been conferred with the power to enforce animal protection legislation (including by bringing prosecutions). Further, humane education remains central to the work of the RSPCA, and has been formally incorporated into legislation through devices such as Animal Welfare Directions - instructions provided by inspectors to animal owners to address the welfare needs of their animal - as a means of forestalling prosecution or avoiding the need for prosecution at all. ${ }^{10}$

In 1835 Martin’s Act was repealed and replaced by legislation championed by Joseph Pease MP. Pease's Act ${ }^{11}$ was more expansive than Martin’s Act, with 'torture' included as prohibited conduct, and bulls, dogs and other domestic animals were included within the category of protected animals (Radford, 2001). Other changes included the extension of the prohibition on animal fighting and baiting from London to the country at large; the imposition of a duty to properly feed an animal in cases of impounding; and provisions specifying that all horses and cattle should be killed within three days of arriving at an abattoir, with the animals to be sufficiently fed daily before slaughter, and not put into use. ${ }^{12}$

By specifically prohibiting the so-called "blood sports”, including bull-baiting, badger-baiting, dog-fighting and, a few years later, cock-fighting, Pease's Act was consistent with the humanitarian reform efforts initiated at the turn of the century, and canvassed earlier in this chapter. Griffin (2005, p 233) acknowledges that this legislation 'has long been regarded as evidence of increasing humanitarian concern amongst social elites'. However, she cautions that the 'practical significance of these laws' should not be overestimated. Bull-baiting, she argues, was in steep decline prior to 1800 . Further, to the extent the legislation focussed on "blood sports" it was

\footnotetext{
law enforcement seemed particularly powerful and daring in 1824, when the regular police force were still new and widely resented as invaders of the privacy of citizens'. See also Anderson (2012).

${ }^{10}$ See Section 5 below.

${ }^{11} 5$ \& 6 Will IV, c 59; An Act to consolidate and amend the several Laws relating to the cruel and improper Treatment of Animals, and the Mischiefs arising from the driving of Cattle.

12 Ibid.
} 
unnecessary, since local authorities had long had the power to control the use of public spaces. The working-class did not possess the large, open spaces required for these sports, so that they were necessarily conducted on public land. Despite this, local authorities rarely exercised the powers available to them under relevant ordinances to shut down these practices. Again, this was largely because the practices were already in decline. Griffin (2005, p 234) argues that:

the 1835 Cruelty to Animals Act was arguably important as an ideological statement, rather than as a political act. Its significance lay not in the new powers it introduced, but in the cultural message, concerning a civilised and enlightened ruling class, that it embodied . . . the decline of bull-baiting looks very much like an example of nineteenth-century social progress, and we are used to looking to social elites to explain progressive cultural shifts of this kind ... however . . . it is necessary to turn away from social elites, to the more nebulous and unquantifiable domain of plebeian cultural tastes if we are to understand the disappearance of bull-baiting.

While Griffin provides an important reminder of the need to avoid over-simplification in rationalising legislative developments in animal protection, her analysis risks the opposite - over-simplifying the law. In particular, regardless of the declining significance of some of the practices targeted by the legislation, a generic prohibition on cruelty was also established, one which continues to shape the contours of animal protection to the present day, not only in the UK, but also in former colonies such as Australia.

\section{Animal Protection Law in Colonial Australia}

Animal cruelty was a subject of public concern at an early stage of Australian colonisation. Referring to a range of newspaper articles in 1804 and 1805, Jamieson (1991b, p 239) states that a 'genuine concern for animal welfare beyond merely protecting their value as property is clearly evident in early nineteenth century colonial Australia. The Sydney Gazette of that period frequently admonishes cruelty to animals'. Despite this, it was not until 1837 in Van Dieman’s Land (Tasmania), that 
the first colonial animal protection legislation was passed. ${ }^{13}$ Although Pease's Act significantly extended the scope of protection provided in Martin’s Act, as discussed above, the latter was more closely emulated in the first colonial legislation in 1837 (Jamieson, 1991a, p 22):

the legislation for the prevention of cruelty to animals introduced in the sittings was only a pale reflection of its more extensive English counterpart of two years previously. While also extending the provisions of "Martin's Act" of 1822 to encompass cruelty to any "domestic animals," it made no further provision, as did its English equivalent, regarding the keeping of pits for animals fights, the provision of sufficient food for impounded animals or the slaughter of horses. ${ }^{14}$

Specific animal protection legislation was next introduced in the colony of New South Wales in $1850 .{ }^{15}$ The 1850 Act was comparatively detailed. It established a basic cruelty offence, but also contained provisions specifically addressing cattle driving, bull-baiting and animal fighting. It adopted a wide-ranging definition of 'animal' ${ }^{16}$ The legislation was also notable for the inclusion of a provision making it an offence to 'convey or carry or cause to be conveyed or carried in or upon any vehicle any animal in such a manner or position as to subject such animal to Unnecessary pain or suffering'. This provision marked the first use of the no 'unnecessary pain or suffering' standard in Australia, on which was adopted in subsequent colonial legislation, and which remains a staple of contemporary regulation of animal protection in the States and Territories. ${ }^{17}$

\footnotetext{
${ }^{13} 8$ William IV, No. 3; An Act for the Better Prevention of Cruelty to Animals $<$ http://www.austlii.edu.au/au/legis/tas/num_act/aaftbpocta8win3611/>. The Act is brief, making it an offence to 'wantonly torture or cruelly beat ill-treat or abuse any Horse Bull Ox Cow Calf Mule Ass Sheep Pig Goat Dog or other Domestic Animal'. For a detailed history of the development of animal protection law in Tasmania see Petrow (2012).

${ }^{14}$ The available evidence suggests that the legislation was enforced through prosecutions at least from 1838. Jamieson (1991a, p 22) states that 'the Hobart Town Courier notes the imposition of fines for convictions of cruelty given against Thomas Dowling (14 September 1838) and Richard Hume (12 October 1838). Records at Richmond Gaol record six days solitary confinement for cruelty given to Charles M in September 1838'.

${ }^{15} 14$ Vic, No 40; An Act for the More Effectual Prevention of Cruelty to Animals $<$ http://www.austlii.edu.au/au/legis/nsw/num_act/ctaa1850n40240.pdf $>$. The key provision provided that if 'any person shall . . . cruelly beat ill treat over-drive abuse or torture or cause or procure to be cruelly beaten ill treated over-driven abused or tortured any animal every such offender shall for every such offence forfeit and pay a penalty not exceeding five pounds': $\mathrm{s} 1$.

${ }^{16}$ The definition referred to 'any horse mare gelding bull ox cow heifer steer calf mule ass sheep lamb hog pig sow or goat or any dog cat or other domestic animal'.

${ }^{17}$ The qualified nature of this standard has been a particular focus of contemporary debate: see, eg, Sankoff (2013); cf Radford (2001).
} 
In New South Wales, and from 1859 in the new colony of Queensland, regulation of animal protection occurred through a specific prevention of cruelty statute. The 1850 statute governed animal protection in New South Wales until a new Act was passed in 1901 and in Queensland until, similarly, a new Act was passed in 1901. Tasmania persisted with an anti-cruelty statute, although a prohibition on animal fighting was included in police legislation in $1865 .{ }^{18}$ In the other colonies, animal protection was effected exclusively through police legislation, including in Western Australia in $1849,{ }^{19}$ South Australia in $1863^{20}$ and Victoria in $1864 .{ }^{21}$ The inclusion of animal protection provisions in police offences legislation in the Australian colonies marked a different approach to that of the UK. At one level, this is only significant in a formal sense. Jamieson (1991b, pp 241-242) acknowledges a shared concern on the part of all jurisdictions to enforce social order through a focus on lower class leisure activities rather than 'the more gentlemanly activities of the hunt'. Accordingly 'the growth of animal cruelty legislation in the colonies as a means of social control [was] reinforced by the early inclusion of such provisions almost exclusively in colonial police offences laws'. However, Jamieson suggests that the exertion of social control was more significant in the colonies: 'the state ... was inevitably a stronger, more intrusive, legitimately interventionist instrument than Victoria’s Britain . . . not having to contend against the traditional restraints of established church, military services, and landed aristocracy'. Consequently, as a matter of substance, it 'not surprising that the police legislation adopted in the colonies was far more intrusive of individual liberty than its English counterpart'.

Apart from the adoption of a "no unnecessary suffering” standard and a residual enforcement role for police, colonial legislation through the mid- $19^{\text {th }}$ century phase also established another key tenet of animal protection law which remains in place today. This involved extending obligations beyond a negative duty not to impose

\footnotetext{
${ }^{18}$ Police Act 1865 (Tas) s 83 <http://www.austlii.edu.au/au/legis/tas/num_act/tpa186529vn10163/> .

1912 Vic No 20; An Ordinance for Regulating the Police in Western Australia, s XX

$<$ http://www.austlii.edu.au/au/legis/wa/num_act/p12vn20131/>.

2026 \& 27 Vic No 10, Police Act 1863 (SA) s 76

$<$ http://www.austlii.edu.au/au/legis/sa/num_act/pa10o26a27v1863168/>

2127 Vic No 225, Police Offences Statute 1864 s 18

$<$ http://www.austlii.edu.au/au/legis/vic/hist_act/tpos1864248/>
} 
cruelty on an animal, to encompass a positive obligation to provide food and water to an animal. ${ }^{22}$

The next wave of animal protection law reform occurred around the turn of $20^{\text {th }}$ century. Three features of reform during this period are particularly noteworthy: first, the introduction of important structural change to animal protection legislation; second, the emergence of the RSPCA as a key enforcement institution; and third, an alliance formed between the animal protection movement, concerned with domesticated animals, and animal preservationists, concerned with protection of wild animals. As to the first of these, a significant development at this time was the introduction of exemptions from the general duty not to be cruel. The first step was taken in Victoria in 1881, with other jurisdictions following after the turn of the century. Exemptions were provided in three key areas: the control of wild animals, use of animals in experiments, and farming. Although now modified through the adoption of a code-based process of exemption, the justifications offered for exemptions have changed little over time. In relation to farming (Jamieson, 1991a, p 30):

[the] historical concentration of animal protection legislation on domesticated animals had early fostered its perception by the rural community as mere urban meddling, the fear that such legislation "would seriously affect country districts" having in no way diminished by the beginning of the twentieth century. Agitation in South Australia in 1906 for the inclusion of a specific provision exempting from the operation of the statute the dehorning of cattle, heightened by the fining of "many people" in Victoria for engaging in this practice, led to the inclusion in the Prevention of Cruelty to Animals Act 1908 (SA) of a provision exempting the operation where "performed with a minimum of suffering to the animal operated upon". This early exemption in favour of the rural community was extended in Western Australia in 1912 to include "the castration, spaying, ear-splitting, ear-marking, or branding of any animal, or the tailing of any lamb". Similar exemptions were adopted in Queensland and Tasmania in 1925 and in New South Wales in 1928.

\footnotetext{
${ }^{22}$ For Jamieson (1991a, p 26) 'little new development is to be found in the cruelty provisions adopted beyond the precedent earlier established by the New South Wales legislation of 1850 . Nevertheless, that early legislation having generally recognized the offence of cruelty and made specific provision in respect of animal fights and the carriage of animals, both Victoria (1854) and South Australia (1863) did make further provision as to the omission to supply an animal with food and water'
} 
Second, once anticruelty legislation was in place in the colonies, institutional support followed through the establishment of the RSPCA. This occurred more slowly than had been the case in the UK after the passage of Martin's Act. Distinct societies were formed in each colony, beginning with Victoria in 1871, and progressing through Tasmania in 1872, New South Wales in 1873, South Australia in 1875 and Western Australia in 1892 (RSPCA Australia, n.d.). In Queensland 'the Queensland Society for the Prevention of Cruelty formed in Brisbane [in 1883], following an unsuccessful attempt in 1876' (Emmerson, 1993, p 7). ${ }^{23}$ It was not until 1923 that 'the Societies were given the Royal Warrant, becoming known as the Royal Societies for the Prevention of Cruelty to Animals'. ${ }^{24}$ Munro (2001, p 13) suggests that '[l]ike its Anglo-American counterparts, the Australian RSPCA consisted predominantly of middle-class urbanites, although in the Australian case, the RSPCA attracted affluent people from rural areas as well'.

A third important strand in the development of animal protection in Australia during the period around the turn of the $20^{\text {th }}$ century was the alliance which emerged between animal protectionists and animal preservationists. The early decades of colonisation were marked by the wide-scale destruction of native wild animals and, at the same time, introduction of wild animals from the UK, in part reflecting attempts to achieve a “Britainisation' of the landscape. Native wild animals were a food source for colonialists until domesticated farm animals were established. Later, a range of factors led to the destruction of vast numbers of wild native animals including land clearing and habitat loss; an assessment of native animals as pests; and the commodification of native animals through the production of furs, pelts and other byproducts for export. ${ }^{25}$ Non-indigenous animals were routinely afforded more protection against hunting than native animals (such as through extended 'close seasons' for introduced animals, or periods during which hunting of specified animals was illegal, compared with native animals). Towards the end of the n19th century,

\footnotetext{
${ }^{23}$ In 1890 the Constitution of the Queensland Society was amended to incorporate protection of children and the name shortened to the "Society for the Prevention of Cruelty". The Society was an active contributor to the successful campaign for child protection legislation in the 1890s. However '[o]ver the twentieth century, the Government gradually assumed a greater role in the protection of children and old people and the Society's involvement declined until it finally ceased around 1970': (RSPCA Queensland).

${ }^{24}$ It was only much later, in 1981, that RSPCA Australia, a national organisation, was created (RSPCA Australia, n.d.).

${ }^{25}$ For a detailed examination of this period of wild animal protection law see White (2013).
} 
however, an animal preservation movement had emerged which sought better protection of all wild animals and, especially, native wild animals. This led to an alliance between animal protectionists and animal preservationists, despite the fact that 'then as now, both movements had different purposes and ideologies; the preservationists focussed their campaigns on saving species and habitats, and they thought little of animal protectionists' concern for preventing cruelty to individual animals’ (Munro, 2001, p 14).

Much of the early wild animal protection legislation took the form of bird protection legislation, in part reflecting an antiplumage campaign which focussed on the indirect cruelty to birds. Munro (2001, pp 13-14) states that the 'antiplumage campaign became a synonym for anticruelty and united both protectionists and preservationists . .. these two movements were irrevocably entwined and, in the popular imagination, synonomous'. ${ }^{26}$ For animal preservationists the invocation of anticruelty was an important way of transforming an understanding of native animals from "vermin" to “cute creatures” worthy of protection, as occurred with a sustained campaign to protect the koala. ${ }^{27}$ On the other hand, the animal protectionist movement benefitted through a broadening of focus, since 'the animal lobby had run out of steam by 1914 . .. due to the movement's transformation from a social-reform lobby to a group of pet enthusiasts who emphasised the genteel promotion of kindness to animals, especially cats and dogs’ (Munro, 2001, p 15).

A final but important aspect of $19^{\text {th }}$ century Australian animal protection law is the wholesale importation of the personal property status of animals at common law. This status reflected an evolution from the medieval era, when animals were commonly put on criminal trial in the ecclesiastical courts of Britain and Europe for a wide range of offences, including murder of children and crop damage (Evans, 1987). ${ }^{28}$ However as Ritvo (1987, p 2) points out:

\footnotetext{
${ }^{26}$ Citing doctoral research by MacCulloch (1993).

${ }^{27}$ The transformation of the koala from rural pest and valuable commodity to national icon occurred over many years. In 1896 'one leading fur company held over one million koala skins for export to Russia’ (Munro, 2001, p 14). As late as 1927 the Queensland Government, in the face of considerable public outcry, permitted the killing of over one million koalas for the international fur trade (White, 2013).

${ }^{28}$ Defence counsel would be appointed for accused animals. On a finding of guilt punishment included excommunication, as well as judicial penalties such as capital punishment.
} 
By the nineteenth century British authorities has stopped sentencing animals to suffer and die for their crimes . . . Nineteenth-century English law viewed animals simply as the property of human owners, only trivially different from less mobile goods. It followed that they were no longer held morally accountable for their actions ...

An influential philosophical justification for the English common law understanding of animals as a form of personal property can be found in familiar Lockean discourse. Animals, in their original state, belong to all of mankind as part of the commons. As with nature generally though, animals are given to humans for their use. When a person removes an animal out of the state of nature, applying their labour in doing so, they make the animal their property. In exercising their labour in relation to animals, humans alter their legal status, the animals becoming goods (Francione, 1995). Significantly, around 75 years after Locke, Blackstone addressed the status of animals in his Commentaries on the Laws of England. In Book II of his Commentaries, directly influenced by Locke, ${ }^{29}$ Blackstone suggested that '[i]n such as are of a nature tame and domestic (as horses, kine, sheep, poultry, and the like), a man may have as absolute a property as in any inanimate beings' (Radford, 2001, p 100). The common law, Blackstone suggested, only protects domesticated animals to the extent that they are of some monetary worth. For example, typically it was only farm or working animals that were capable of being the subject of theft.

The idea of absolute property in domesticated animals was quickly established in the Australian colonies. In part this was due to the fact that 'the law as enshrined in Blackstone carried significant weight in the early years of the [NSW] Superior Court' (Salter, 2009, p 40). ${ }^{30}$ Regardless of developments occurring in animal protection, Salter (2009, p 40) argues that:

it was the issue of animal possession, framed by the earlier eighteenth century of the likes of Blackstone, which would pre-occupy the courts of N.S.W. in the late eighteenth and early nineteenth century. Although situations of animal cruelty would continually arise in the facts

\footnotetext{
${ }^{29}$ Francione (1995, p 39) suggests that "Locke's theory of property had an extraordinary influence on the common law'.

${ }^{30}$ Citing Castles (1982).
} 
of civil and criminal superior court trials, the protection of the animal was always legally invisible next to the primary issue of animal possession.

\section{Animal Protection Law in Post-Federation Queensland}

The trajectory of the implementation of animal protection law in the various Australian colonies followed a similar structural if not temporal path. This pattern continued post-federation. However, to avoid over-simplification and for practical reasons of space, this Section narrows the focus to a particular jurisdiction in considering post-federation development. Four key stages in the evolution of animal protection law in post-federation Queensland will be addressed. These are the introduction of the first Queensland specific legislation in 1901, a new Act in 1925, a failed reform attempt in the 1990s, and a new Act in 2001. Looking across these legislative developments a consistent approach to the overarching regulatory standards for the protection of animals can be identified, even if the detail of the regulation becomes more detailed over time.

Queensland was established as a colony separate from New South Wales in 1859. However, the animal protection statute passed in New South Wales in 1850, discussed in Section 4, remained the law of colonial Queensland until 1901, when a new animal protection statute was introduced for the State of Queensland. ${ }^{31}$ This legislation included the key characteristics of animal protection legislation developed and applied in most jurisdictions during the nineteenth century, including nominal application to all animals, ${ }^{32}$ a prohibition against cruelty, ${ }^{33}$ the imposition of duty of care-like obligations, ${ }^{34}$ and qualification of the cruelty prohibition effected through adoption of a “no unnecessary suffering” standard ${ }^{35}$ and limited exemptions. ${ }^{36}$

\footnotetext{
${ }^{31}$ The Animals Protection Act of 1901 (Qld). A minor change to the 1850 NSW legislation had earlier expanded the category of 'animal' to include camels: Criminal Law and Evidence Amendment Act 1891 (NSW) s 35.

32 'Animal' was defined as 'every species of animal whether in a natural or domestic state': s 3.

${ }^{33}$ Section 5(1) provided: 'No person shall do any act or observe any forbearance towards any animal which act or forbearance involves cruelty'.

${ }^{34}$ Section 7 provided: 'No person who has the possession or the custody of any animal which is confined or otherwise unable to provide for itself shall omit to provide such animal during so long as it remains so confined in his possession or custody with proper and sufficient food, drink, and shelter'. ${ }^{35}$ Section 3 defined cruelty as: 'The intentional or deliberate infliction upon any animal of pain that in its kind or degree or its object or its circumstances is unreasonable or wanton or malicious'.

${ }^{36}$ Exemptions included for 'the extermination of rabbits, marsupials, wild dogs or vermin', hunting of wild animals and use of animals in scientific research: s 12(1).
} 
RSPCA Queensland actively lobbied for the passage of the 1901 legislation, concerned to more effectively protect animals and, more prosaically, to burnish its authority to address enforcement issues (Emmerson, 2001). However, the 1901 Act left the RSPCA with 'no legal standing and its officers no more authority than any other citizen’ (RSPCA Qld, n.d.). This lack of standing was remedied in a new Act passed in 1925. ${ }^{37}$ The 1925 legislation, 'modelled on English and Western Australian legislation of the time', specifically conferred powers on officers of the RSPCA to enter premises and check for compliance (Emmerson, 2001, p 13). The 1925 legislation maintained the key characteristics of the 1901 Act. ${ }^{38}$ However, the range of exemptions was extended to include religious slaughter ${ }^{39}$ and a number of common animal husbandry practices. ${ }^{40}$ As well, the legislation was notable for making a further sanction available to a court in dealing with an owner convicted of animal cruelty - depriving the convicted person of future ownership of their animal. ${ }^{41}$ In addition to a fine and/or imprisonment, temporary or permanent prohibition against ownership of an animal is a staple of modern sanctions available to sentencing courts.

Apart from some minor amendments, the Queensland legislation remained largely intact into the 1990s. At this time, a major reform effort was initiated by the State Government, at the tail end of animal protection reform projects instigated in a number of other jurisdictions. There had been 'a resurgence of legislative activity in the field of animal protection. In the humanitarian spirit of the eighties, the welfare state turned its attention towards the revision of the scope and philosophy of its animal protection legislation' (Emmerson, 1993, p 18). The Animal Protection Act Review Committee was established to review the 1925 legislation, with the Committee drawing on a wide base for input, including the police, animal protection

\footnotetext{
${ }^{37}$ The Animals Protection Act of 1925 (Qld).

${ }^{38}$ The definition of cruelty was changed in the 1925 Act, to unreasonable, unnecessary or unjustifiable ill-treatment. In a circular approach, ill-treatment was then defined to include a range of cruel practices. As Hill (1985, p 9) argues 'this definition says little more than that cruelty means unreasonable, unnecessary or unjustifiable cruelty. Surely all ill-treatment is cruel, and certainly in the terms proposed in the Act. The words are synonymous'.

${ }^{39}$ The Animals Protection Act of 1925 (Qld) s 7(1)(a).

${ }^{40}$ Ibid s 7(1)(b) ('dehorning of cattle, or the castration, speying, ear-splitting, ear-marking, or branding of any animal, or the tailing of any lamb, where the operation is performed with a minimum of suffering to the animal operated upon').

${ }^{41}$ Ibid s 19.
} 
advocacy groups, farm industry sectors, veterinarians and animal welfare scientists (Emmerson, 2001). Possible reform options were canvassed in a Green Paper in 1990, and draft legislation then prepared. Change was needed to respond to 'changing community attitudes towards animal welfare matters, advancements in scientific knowledge and animal behaviour, and to encourage consistency in animal welfare legislation throughout Australia' (Emmerson, 1993, p 35). The ideal of consistency emerged most clearly in October 1991, when the first Animal Welfare Ministers Conference was staged in Adelaide. State and Territory Ministers collectively agreed to strive for uniformity in legislation in each of the Australian jurisdictions (Emmerson, 2001). Although slow to take hold, an agenda of consistency was actively pursued by the Commonwealth and the States and Territories, later reflected in the broad policy umbrella of the Australian Animal Welfare Strategy (AAWS) (Commonwealth of Australia, 2011). One of the goals of this strategy was to achieve uniform farm animal welfare standards. ${ }^{42}$

Despite the extensive ground work undertaken to prepare an overhaul of the Queensland legislation in the early 1990s, a Bill was not presented to Parliament. In July 1993 drafting proposals for the Bill were leaked to Brisbane’s metropolitan newspaper, The Courier-Mail, with a range of groups critical of their content, including the police and a number of animal protection advocacy organisations (Emmerson, 2001). According to Emmerson (2001, p 14), the most influential voice was that of the RSPCA:

The most vocal opponent of the proposed Bill was the RSPCA, which believed it weakened animal protection in the state rather than improving the situation. The RSPCA claimed that the government had ignored the recommendations of the Advisory Committee, releasing drafting guidelines not agreed to by the committee. The RSPCA obtained legal opinion on the drafting guidelines, which suggested the proposals required changing. As a result, the RSPCA began the Kill the Bill, Not Animals campaign. This involved mounting public support against the Bill. They sent a public letter of protest to the Minister, and asked that supporters do the same. Acrimonious debate followed. There was a great deal of media attention devoted to the

\footnotetext{
${ }^{42}$ For detailed discussion see Dale and White (2013). The Commonwealth Government has recently retreated from a leadership role in the animal welfare policy field, reflected in the defunding of the AAWS, with the consequences for the national consistency goal uncertain at best (Commonwealth Government, 2013).
} 
discussion of the proposed Bill. As a result, the animal welfare groups were successful in preventing the Bill becoming law at that time.

Apparently chastened by the strength of the RSPCA response to the proposed Bill, the Government subsequently successfully passed revised legislation in 2001. ${ }^{43}$ RSPCA Queensland was supportive of the legislation, especially after the powers conferred on inspectors were extended, an issue that had been a key reason for objection to the 1993 reform attempt (Emmerson, 2001).

In terms of the key tenets of animal protection legislation discussed already, perhaps the most significant features of the new Act were:

- the imposition of a statutory "duty of care" based on the 'Five Freedoms" 44 with breach punishable by a maximum fine of $\$ 22,500$ and/or one year’s imprisonment; 45

- a significant increase in penalties for a cruelty offence, from a maximum \$1500 fine and/or six months imprisonment under the 1925 Act to a maximum $\$ 75,000$ fine and/or two tears imprisonment under the 2001 Act;

- the incorporation of welfare Codes of Practice, particularly for farm animals (under regulations); ${ }^{46}$

- $\quad$ an exemption from prosecution for the cruelty and breach of duty of care offences where there is compliance with a code of practice; and

- the introduction of Animal Welfare Directions, a tool allowing for directions to be given to a person in charge of an animal to comply with their statutory

\footnotetext{
${ }^{43}$ Animal Care and Protection Act 2001 (Qld).

${ }^{44}$ These are the freedom from hunger, thirst and malnutrition; freedom from fear and distress; freedom from physical and thermal discomfort; freedom from pain, injury and disease; and freedom to express normal patterns of behavior. The origin of the Five Freedoms can be traced back to the 1960s Brambell Committee inquiry into the treatment of farm animals in Great Britain (Brambell et al, 1965). ${ }^{45}$ In 1991 the Queensland Association for Community and Animal Welfare proposed that a "stewardship" obligation be included in Queensland animal protection law, in terms very similar to the duty of care obligation included in the 2001 Act (Thelander, 1991).

${ }^{46}$ Farming industry attitudes to codes of practice seemed to shift dramatically between the mid-1980s, when their adoption under legislation in Queensland was first proposed, and the early 1990s. For example, in 1985 grazing animal farmers were expressing the view that 'codes of conduct are not necessary for the grazing animal industry since it operates well, and has done so for many years without any such code in place’ (Peart, 1985, p 173). By 1991 the United Graziers’ Association was arguing that '[i]n our view, the correct strategy is to use the Codes of Practice as a guideline, with the Codes tied to legislation’ (Joyce, 1991, p 57).
} 
obligations, and 'aimed at being proactive, preventing a potential animal cruelty offence from occurring, or resolving an existing problem’ (Emmerson, 2001).

The same essential elements of this legislation remain in place to the present day.

\section{Conclusion}

This chapter examined changing attitudes to the treatment of animals in nineteenth century Britain, tracing the effects of change through to the first British animal protection legislation in 1822, and beyond to the law of the Australian colonies. By the early part of the twentieth century a number of key facets of animal protection regulation were established: the adoption of the generic "no unnecessary suffering" standard in assessing the extent of cruelty to animals allowed; the use of exemptions from the generic prohibition against cruelty; the imposition of duties to provide for the needs of an animal; and the establishment of one of the key institutional actors in the animal protection field, the RSPCA. As well, the Australian colonies faithfully reproduced an understanding of domesticated animals as personal property. This property-based approach was consistent with a Lockean liberal property theory, reflected in William Blackstone's delineation of the principles of the common law. As shown through an exploration of the key animal protection law developments in post-federation Queensland, these facets of animal protection have proven to be enduring, helping to define the nature and limits of contemporary regulation.

The key principles of animal protection regulation established during the $19^{\text {th }}$ and early $20^{\text {th }}$ centuries were a response to the particular socio-political concerns of reformist $19^{\text {th }}$ century Britain. They were built on an ethic of humaneness, an ethic which, by and large, continues to animate contemporary orthodox understanding of the significance of animal interests. This 'Wilberforce ethic' holds that 'while humans had control over animals and could use them for any purpose, such use must be justified and humane' (Wirth, 2007). As Wirth (2007, p 2) points out, 'the Wilberforce philosophy of animal welfare remains the keystone of the humane movement today'. However, at least since the 1970s, debates in animal ethics have undermined the persuasiveness of the idea that animals are due only humane 
protection. These debates suggest a greater significance for animal interests than this ethic allows. ${ }^{47}$ This has important implications for key principles of contemporary animal protection legislation, including a legal standard such as "no unnecessary suffering”, grounded as they are in $19^{\text {th }}$ century UK responses to changing social conditions, visible animal cruelty and contingent political debates. In particular, does the present day animal protection regulatory framework found in Australian jurisdictions amount, in essence, to a $19^{\text {th }}$ century answer to $21^{\text {st }}$ century concerns?

\section{References}

Anderson, Jerry. 2012. The Origins and Efficacy of Private Enforcement of Animal Cruelty Law in Britain. Drake Journal of Agricultural Law 17: 263-310.

Armstrong, Susan and Richard Botzler. 2008. General Introduction - Animal Ethics: A Sketch of How It Developed and Where It is Now. In The Animal Ethics Reader. $2^{\text {nd }}$ ed. eds. Susan Armstrong and Richard Botzler, 1-13. London: Routledge.

Bonyhady, Tim. 2000. The Colonial Earth. Carlton: Melbourne University Press.

Brambell, F W Rogers et al. 1965. Report of the Technical Committee to Enquire into the Welfare of Animals Kept Under Intensive Livestock Husbandry Systems. A Report to the Great Britain Minister of Agriculture, Fisheries and Food. London: HMSO.

Castles, Alex. An Australian Legal History. Sydney: Law Book Co.

Commonwealth of Australia. 2011. Australian Animal Welfare Strategy and National Implementation Plan 2010-2014. http://www.daff.gov.au/animal-plant-

\footnotetext{
${ }^{47}$ For a succinct account of the range of challenges to an ethic of humaneness see Garner (2005).
} 
health/welfare/aaws/australian-animal-welfare-strategy-aaws-and-nationalimplementation-plan-2010-14. Accessed 30 October 2014.

Commonwealth Government. 2013. Mid-Year Economic and Fiscal Outlook 20132014. Appendix A, 97 \& 115. http://www.budget.gov.au/2013-

14/content/myefo/download/12_appendix_a_expense.pdf. Accessed 30 October 2014.

Dale, Arnja and Steven White. 2013. Codifying Animal Welfare Standards:

Foundations for Better Animal Protection or Merely a Façade? In Animal Law in Australasia: Continuing the Dialogue, $2^{\text {nd }}$ ed. eds Peter Sankoff, Steven White and Celeste Black, 151-182. Sydney: Federation Press.

Emmerson, Glenda. April, 1993. Duty and the Beast: Animal Welfare Issues.

Background Information Brief No 25. Brisbane: Queensland Parliamentary Library.

Emmerson, Glenda. 2001. Duty and the Beast: Animal Care and Protection Bill 2001. Research Brief No 2001/23. Brisbane: Queensland Parliamentary Library.

Evans, Edward. 1906, rev ed 1987. The Criminal Prosecution and Capital Punishment of Animals. London: Faber \& Faber.

Favre, David and Vivian Tsang. 1993. The Development of Anti-Cruelty Laws During the 1800's. Detroit College of Law Review 1: 1-35.

Francione, Gary. 1995. Animals, Property and the Law. Philadelphia: Temple University Press.

Garner, Robert. 2005. Animal Ethics. Cambridge: Polity Press.

Griffin, Emma. 2005. England's Revelry: A History of Popular Sports and Pastimes 1660-1830. Oxford: Oxford University Press.

Harrison, Brian. 1973. Animals and the State in Nineteenth-Century England. English Historical Review 88: 786-820. 
Hill, John. 1985. The Legality of Cruelty. In Grazing Animal Welfare Symposium. eds. Brian Moore and Peter Chenoweth. Brisbane: Australian Veterinary Association (Queensland).

Jamieson, Philip. 1991a. Animal Welfare: A Movement in Transition. In Law and History in Australia: A Collection of Papers Presented at the 1989 Law and History Conference. ed. Suzanne Corcoran. Adelaide: Adelaide Law Review Association.

Jamieson, Philip. 1991b. Duty and the Beast: The Movement of Reform in Animal Welfare Law. University of Queensland Law Journal 16: 238-255.

Joyce, Jan. 1991. Animal Welfare - The Graziers’ Perspective. In Proceedings of the Animal Welfare Conference. Brisbane: Queensland Department of Housing and Local Government.

Kean, Hilda. 1998. Animal Rights: Political and Social Change in Britain since 1800. London: Reaktion.

MacCulloch, Jennifer. 1993. Creatures of Culture: The Animal Protection and Preservation Movements in Sydney, 1880-1930. PhD Thesis: University of Sydney.

Munro, Lyle. 2001. Compassionate Beasts: The Quest for Animal Rights London: Praeger.

O’Sullivan, Siobhan. 2011. Animals, Equality and Democracy. Basingstoke: Palgrave MacMillan.

Peart, W J. Codes of Conduct for Grazing Animal Welfare: The Graziers’ View. In Grazing Animal Welfare Symposium. eds. Brian Moore and Peter Chenoweth. Brisbane: Australian Veterinary Association (Queensland). 
Petro, Stefan. 2012. Public Opinion, Private Remonstrance, and the Law: Protecting Animals in Australia, 1803-1914. In Past Law, Present Histories. ed. Diane Kirkby, 61-84. Canberra: ANU Press.

Radford, Mike. 2001. Animal Welfare Law in Britain: Regulation and Responsibility. Oxford: Oxford University Press.

Ritvo, Harriet. 1987. The Animal Estate: The English and Other Creatures in the Victorian Age. Cambridge, Mass.: Harvard University Press.

RSPCA Australia. n.d. Our History. http://www.rspca.org.au/what-we-do/aboutus/our-history. Accessed 30 October 2014.

RSPCA Queensland. n.d. Where We Were. http://www.rspcaqld.org.au/who-weare/our-history. Accessed 30 October 2014.

RSPCA UK. n.d. Our History. http://www.rspca.org.uk/in-action/aboutus/heritage. Accessed 30 October 2014.

Ryder, Richard. 2000. Animal Revolution: Changing Attitudes Towards Speciesism. rev ed. Oxford: Berg.

Salter, Brett. 2009. Possess or Protect? Exploring the Legal Status of Animals in Australia's First Colonial Courts: Part I. Australian Animal Protection Law Journal 2: 35-48.

Sankoff, Peter. 2013. The Protection Paradigm: Making the World a Better Place for Animals. In Animal Law in Australasia: Continuing the Dialogue, $2^{\text {nd }}$ ed. eds Peter

Sankoff, Steven White and Celeste Black, 8-23. Sydney: Federation Press.

Thelander, Andrew. 1991. Positive Concepts in Legislative Reform. In Proceedings of the Animal Welfare Conference. Brisbane: Queensland Department of Housing and Local Government. 
Turner, James. 1980. Reckoning with the Beast: Animals, Pain and Humanity in the Victorian Mind Baltimore: John Hopkins University Press.

White, Steven. 2013. British Colonialism, Australian Nationalism and the Law:

Hierarchies of Wild Animal Protection. Monash University Law Review 39: 452-472.

Wirth, Hugh. 2007. The Animal Welfare Movement and Consumer-driven Change. Farm Policy Journal 4: 1-9. 